\title{
THE ROLE OF E-TRAINING, CAREER DEVELOPMENT, AND EMPLOYEE RESILIENCE IN INCREASING EMPLOYEE PRODUCTIVITY IN INDONESIAN STATE-OWNED ENTERPRISES
}

\author{
Nadira Nurul Janna \\ Universitas Negeri Jakarta, Jakarta, Indonesia \\ nadiranurulianna_1708819007@mhs.uni.ac.id \\ Christian Wiradendi Wolor \\ Universitas Negeri Jakarta, Jakarta, Indonesia \\ christianwiradendi@unj.ac.id \\ Usep Suhud \\ Universitas Negeri Jakarta, Jakarta, Indonesia \\ usuhud@unj.ac.id
}

\begin{abstract}
.
This study analyzes the effect of e-training, career development, and employee resilience on employee productivity of State-Owned Enterprises for Survey Services in Indonesia. The sample in this study were employees of one of the State-Owned Enterprises for Survey Services. The sampling technique used is purposive sampling with a valid response of 270 respondents. The research method used is quantitative. Data was collected by distributing questionnaires using a five-point Likert scale. Data were analyzed using exploratory factor analysis and Structural Equation Modeling (SEM) using Amos 24. The results showed that e-training and career development had a significant positive effect on employee resilience. Career development and employee resilience had a significant positive effect on employee productivity. In contrast, e-training does not affect employee productivity. The results of this study provide useful implications for policymakers to determine company strategies related to e-training, career development, and employee resilience to increase employee productivity.
\end{abstract}

Keywords: e-training, career development, employee resilience, employee productivity.

\section{INTRODUCTION}

Indonesia is facing the industrial revolution 4.0 with technology that is developing very quickly in digitalization technology, robotization, intelligent automation, internet of things (IOT), artificial intelligence, big data, 
machine learning, and so on that can have an impact in various sectors of life such as the economy, national and global business, society and individuals (Heri, 2019).

The human resources needed are those who can understand technology quickly, are adaptive and responsive to technological changes, and have a service attitude and high integrity (Sihite, 2018). It is necessary to reform human resources investment that involves training and human resource development to increase productivity, improve performance and develop employee competencies to be adaptable. (Yunita, 2018).

Career development and training can improve employee performance to increase productivity in the company (Massie et al., 2015). Career development will benefits companies and individuals because it can improve employee performance and productivity, reduce labor turnover, facilitate the fulfilment of the company's internal HR staffing needs, and increase promotions for employees (Permatasari, 2006). At this time, e-training has developed, namely types of electronic training such as video conferencing and webbased training (Ramayah et al., 2012).

To increase productivity, employees are needed who have high flexibility, are dynamic, and have resilience in dealing with problems and crises that occur in the company (Zehir \& Narcıkara, 2016). The level of resilience possessed by an employee will impact his performance in doing a job. Resilience is often considered a common thing formed by social background, family, and career experience. However, being a resilient employee is a skill that can be learned, trained, and formed (Emmanuella, 2020).

Research on 645 employees working in the private sector found that employee resilience positively affects employee productivity. When employees have a high level of resilience, it will increase employee productivity (Zehir \& Narcıkara, 2016). Luthans et al. (2006) stated that employee resilience could be improved through training because individual resilience increases significantly after the training program. This does not happen in other groups who do not receive the training program. Except training provided by the company, career opportunities can help employees deal with the stress. In other words, career development can increase employee resilience (Khan et al., 2019).

This study examines the direct effect of e-training, career development, and resilience on employee productivity. This study attempts to answer the following research questions: (1) does e-training affect employee productivity and employee resilience? (2) does career development affect employee resilience and employee productivity? (3) does employee resilience affect employee productivity?

\section{LITERATURE REVIEW AND HYPOTHESES}

\subsection{E-training and Employee Productivity}


E-learning is learning whose implementation using the help of electronic devices, such as computers, smartphones, audio, videotape, or networks (Batubara et al., 2018). E-learning-based training is training that uses information technology as the delivery method regarding the time frame, much shorter lessons are usually specially designed to achieve specific learning goals or skills. Type standard electronic training is video conferencing and training Web-based. This technology is intended to enable the delivery of new, better, cheaper, and more learning faster than traditional classroom methods (Ramayah et al., 2012). Training can increase not only employee productivity but also organizational productivity (Nda \& Fard, 2013). Many studies have proven that training is a fundamental and practical instrument in producing high productivity (Malaolu \& Ogbuabor, 2013). As research by Nda and Fard (2013), llyas et al. (2017), Nurshabrina and Andrianti (2020), Sabir et al. (2014), e-training can increase employee focus and make it easier for employees to understand their respective job desc because the material provided in the online training is based on theoretical and practical realities that have been adapted to the job desc, this has been proven in his research that e-training has a significant positive relationship on employee productivity. Thus, $\mathrm{H} 1$ is e-training a significant positive effect on employee productivity.

\subsection{E-training and Employee Resilience}

Employee resilience describes the extent to which employees succeed cope with change and setbacks in the workplace and where they are adapted to thrive in a new environment (Nguyen et al., 2016). Resilience plays an important role in managing positive stress. That resilience may be characterized as a coping response to adverse events and positive outcomes, such as promotions or new job responsibilities (Luthans et al., 2008).

Training provided to employees is one of the important things for companies to improve employee resilience and welfare (Hodliffe, 2014). Smith et al. (2018), in their study of 600 respondents sponsored by meQuilibrium, showed that online training programs have a positive effect on resilience, stress, and symptoms in proportion to the time of use. Vanhove et al. (2016) conducted a meta-analysis by evaluating 37 studies that considered training to increase resilience. Employee training and development can improve adaptive skills and problem-solving to cope with stress to increase employee resilience through a sense of belonging and support (Khan et al., 2019). Thus, H2 is e-training has a significant positive effect on employee resilience.

\subsection{Career Development and Employee Resilience}

Careers are separate but related sets of work, providing continuity, serenity and meaning in one's life, and a series of role experiences ordered by place increased responsibility, status, power, rewards, and career, as well as all the work done during the current working period (Arifin, 2013). Career development is a continuous process of an individual through a formally designed series of levels by the organization 
or company through a focus on developing human resources to meet the organization's needs (Dayona \& Rinawati, 2016).

A study conducted by Kuntz et al. (2017), 162 white-collar employees of the four organizations, showed that the sale positively influences employee resilience. Research by Lyons et al. (2015) entitled Resilience in the Modern Career that people who have their own career development goals are more resilient, which means that career development has a positive relationship with resilience. Srivastava dan Madan (2020) conducted a study on 272 middle-level managers in New Delhi, describing that resilience has a positive and significant relationship with their career satisfaction. They have better control over their work even in difficult times. Thus, $\mathrm{H} 3$ is a career development significant positive effect on employee resilience.

\subsection{Career Development and Employee Productivity}

Career development is a way for organizations to support or increase employee productivity while preparing them to face a changing world (Permatasari, 2006). Career development is increasing the workability individuals achieve to achieve the desired career (llah et al., 2020). Career development is a process of changing a situation or particular conditions in a positive direction through a series of positions, job or job titles, including the formal activation structure, offered company to employees to improve awareness, knowledge, and ability to work effectively and support employee career advancement (Ginting, 2003).

Career development is a joint activity between individual employees and the organization. Both parties must do what is required to ensure a thriving work climate that will result in maximum productivity (Gyansah \& Guantai, 2018). Research by Chen et al. (2004) about career development and employee productivity in Thailand shows a positive and significant relationship between career development and employee productivity. Kelana et al. (2016) mention that career development is a systematic career management and can produce productive skills needed in the future. From research conducted, career development is one of the factors that can increase employee productivity. Thus, $\mathrm{H} 4$ is the existence of a positive and significant influence between career development and employee productivity.

\subsection{Employee Resilience and Employee Productivity}

Productivity is the ability of an employee to perform certain tasks according to standards of accuracy, completeness, cost, and predetermined speed (Sultana et al., 2012). According to Hanaysha (2016), employee productivity can be assessed regarding a person's effectiveness in performing their duties. It can be evaluated about the output it produces over a certain period.

Stress felt by employees can reduce employee performance, productivity, morale, and strain relationships at work (White, 2011) because employees who experience excessive stress have difficulty managing emotions, paying attention, making decisions, and thinking clearly. Research conducted in Turkey 
revealed that employee resilience has a positive and significant influence on employee productivity. This research is also supported by other research conducted on telecommunications companies in Indonesia which states that employee resilience affects employee productivity (Saifudin, 2018). Thus, H5 is the existence of a positive and significant effect between employee resilience and productivity of employees. Based on the literature discussion above, the research model is shown in Figure 1. The variables in this study were two exogenous constructs and two endogenous constructs. Career development and training based on e-learning are exogenous constructs. Employee resilience and employee productivity are endogenous constructs.

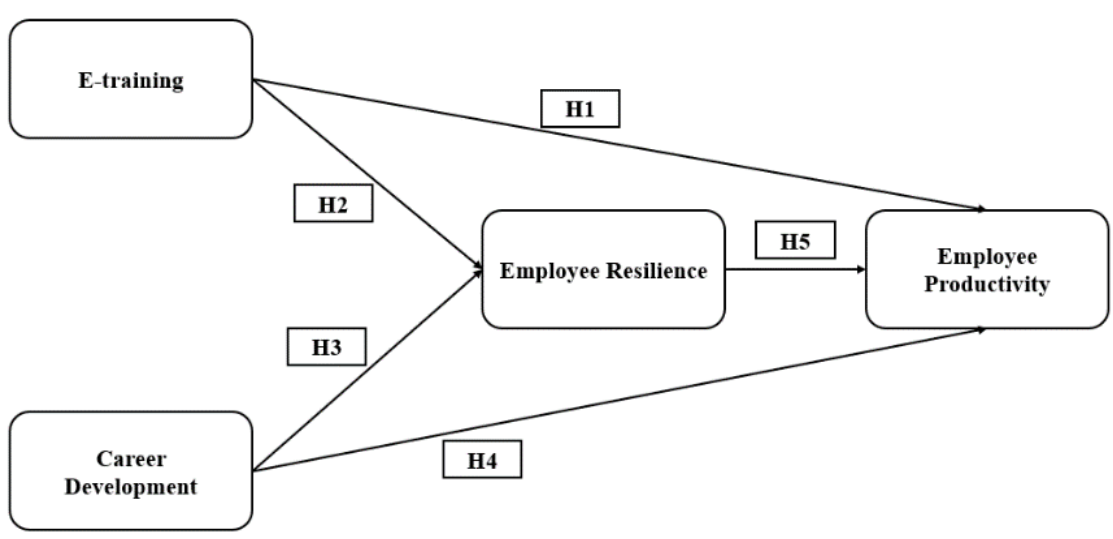

FIGURE 1. RESEARCH MODEL

Source: Author's Research Model

\section{METHODS}

\subsection{Participants}

Respondents in this study were employees of one of the State-Owned Enterprises (SOE) for Survey Services. The sampling method in this study uses a purposive sampling technique to determine specific criteria that are following the research objectives. The reason underlying the determination of the sample using specific considerations is that the data obtained later can be more representative (Cooper \& Emory, 1996). The criteria taken are employees who have participated in the e-training program during the pandemic. Data was collected by distributing questionnaires using Google Form media. The research sample taken is 270 respondents. The sample size has met the minimum sample criteria in data processing using SEM. 


\subsection{Measurement}

This research was conducted in Indonesia. Therefore the statement from the questionnaire was adapted into Indonesian. Five item statements from Hanaysha (2016) were adapted to measure employee productivity. Nine statement items from Hodliffe (2014) were adapted to measure employee resilience variables. Seven statement items from Din (2010) were adapted to measure the e-training variable. Seven statement items from Neureiter and Traut-Mattausch (2016) were adapted to measure career development variables. The questionnaire uses a five-point Likert scale. The operational definition of the variable is presented in Table 1.

TABLE 1. OPERATIONAL DEFINITIONS

\begin{tabular}{|l|l|}
\hline \multicolumn{1}{|c|}{ Variable } & \multicolumn{1}{c|}{ Operational definition } \\
\hline $\begin{array}{l}\text { Employee } \\
\text { Productivity }\end{array}$ & $\begin{array}{l}\text { Employee productivity is assessed based on several aspects such as the level } \\
\text { of effectiveness, efficiency, quality, and quantity of employees to do the job. }\end{array}$ \\
\hline $\begin{array}{l}\text { Employee } \\
\text { Resilience }\end{array}$ & $\begin{array}{l}\text { The ability of employees to develop positively, cope with, and adapt to changes } \\
\text { in the work environment is facilitated by organizational initiatives to utilize } \\
\text { resources. }\end{array}$ \\
\hline E-training & $\begin{array}{l}\text { Training that uses information technology as a method of delivery regarding } \\
\text { much longer learning time frame that is usually designed specifically to achieve } \\
\text { certain learning goals or skills. }\end{array}$ \\
\hline $\begin{array}{l}\text { Career } \\
\text { development }\end{array}$ & $\begin{array}{l}\text { A series of levels designed by the company to prepare competent employees } \\
\text { later to meet the company's needs. }\end{array}$ \\
\hline
\end{tabular}

Source: Author

\subsection{Data Analysis Technique}

The data analysis technique used was exploratory factor analysis to test the validity of the research instrument, Cronbach's alpha for reliability testing, and descriptive statistical analysis to analyze the characteristics of respondents using SPSS 25 software. Furthermore, to measure the research model and test hypotheses, confirmatory factor analysis and Structural Equations Model (SEM) using the goodness of fit (GOF) on the AMOS 24.

\section{RESULTS}

\subsection{Participant Characteristics}

Respondents in this study were permanent employees and contract employees at the State-Owned Enterprises for Survey Services, with a total of 270 respondents. Male respondents were $66.3 \%$, and female respondents were $33.7 \%$. In the age range, as many as $21.5 \%$ in the age range of $18-25$ years, $54.8 \%$ of respondents aged $26-35$ years, $10.4 \%$ aged $36-40$ years, and $13.3 \%$ of respondents over 45 years. $47.8 \%$ of respondents are married, $41.1 \%$ are single, $0.4 \%$ are divorced, and $0.7 \%$ of couples die. 
THE ROLE OF E-TRAINING, CAREER DEVELOPMENT, AND EMPLOYEE RESILIENCE IN INCREASING EMPLOYEE PRODUCTIVITY IN INDONESIAN STATE-OWNED ENTERPRISES

In terms of education, most respondents are undergraduates with $74.1 \%$, followed by a Diploma at $18.5 \%$, then high school at $5.2 \%$, and a master at $2.2 \%$. The respondents' employment status was $51.1 \%$ permanent employees and $48.9 \%$ were contract employees with $93.3 \%$ staff positions and $6.7 \%$ manager positions. Respondents worked in several divisions, namely AKL (21.9\%), AKU (10.7\%), MGK (14.8\%), TEK (13.3\%), KAL (9.6\%), PPP (12.6\%), DUKBIS (13.0\%), and JMMRR (4.1\%). The working period of respondents with a range of $0-5$ years (48.5\%), $6-10$ years (22.6\%), $11-15$ years (13.0\%), $16-20$ years $(2.6 \%)$, and over 20 years $(13.3 \%)$.

TABLE 2. PARTICIPANT CHARACTERISTICS

\begin{tabular}{|c|c|c|}
\hline & $\mathrm{n}$ & $\%$ \\
\hline \multicolumn{3}{|l|}{ Gender } \\
\hline Female & 91 & 33.7 \\
\hline Male & 179 & 66.3 \\
\hline \multicolumn{3}{|l|}{ Age } \\
\hline $18-25$ & 58 & 21.5 \\
\hline $26-35$ & 148 & 54.8 \\
\hline $36-45$ & 28 & 10.4 \\
\hline$>45$ & 36 & 13.3 \\
\hline \multicolumn{3}{|l|}{ Marital Status } \\
\hline Divorce & 1 & 0.4 \\
\hline Married & 156 & 57.8 \\
\hline Single & 111 & 41.1 \\
\hline Others & 2 & 0.7 \\
\hline \multicolumn{3}{|l|}{ Education } \\
\hline High school/secondary education & 14 & 5.2 \\
\hline Diploma & 50 & 18.5 \\
\hline Bachelor's degree & 200 & 74.1 \\
\hline Postgraduate degree & 6 & 2.2 \\
\hline \multicolumn{3}{|l|}{ Employment Status } \\
\hline Contract Employee & 138 & 51.1 \\
\hline Permanent Employee & 132 & 48.9 \\
\hline \multicolumn{3}{|l|}{ Position } \\
\hline Staff & 252 & 93.3 \\
\hline Structural & 18 & 6.7 \\
\hline \multicolumn{3}{|l|}{ Division } \\
\hline$\overline{A K L}$ & 59 & 21.9 \\
\hline AKU & 29 & 10.7 \\
\hline DUKBIS & 35 & 13.0 \\
\hline
\end{tabular}


Janna, N.N., Wolor, C.W., Suhud, U.

THE ROLE OF E-TRAINING, CAREER DEVELOPMENT, AND EMPLOYEE RESILIENCE IN INCREASING EMPLOYEE PRODUCTIVITY IN INDONESIAN STATE-OWNED ENTERPRISES

\begin{tabular}{|l|c|c|}
\hline JMMRR & 11 & 4.1 \\
\hline KAL & 26 & 9.6 \\
\hline MGK & 40 & 14.8 \\
\hline PPP & 34 & 12.6 \\
\hline TEK & 36 & 13.3 \\
\hline Working Period (years) & 131 & 48.5 \\
\hline $0-5$ & 61 & 22.6 \\
\hline $6-10$ & 35 & 13.0 \\
\hline $11-15$ & 7 & 2.6 \\
\hline $16-20$ & 36 & 13.3 \\
\hline$>20$ & &
\end{tabular}

Source: Author

\subsection{Validity and Reliability Test}

The technique used to estimate reliability in this study uses Cronbach's alpha with a value of $a>0,60$ (Ghazali, 2017). While the guideline for the factor loading value on the EFA used is 0.35 because it is based on the number of samples, which is 270 (Hair et al., 2014). The results of the calculation of factor loading and Cronbach's alpha can be seen in Table 3.

TABLE 3. EXPLORATORY FACTOR ANALYSIS

\begin{tabular}{|c|c|c|c|}
\hline Code & Variables and Indicators & $\begin{array}{l}\text { Factor } \\
\text { Loadings }\end{array}$ & $\begin{array}{l}\text { Cronbach's } \\
\text { Alpha }\end{array}$ \\
\hline & \multicolumn{2}{|l|}{ Employee Productivity } & $a=0.910$ \\
\hline PP3 & I have a high standard of job achievement & 0.921 & \\
\hline PP1 & I do a lot of work every day & 0.913 & \\
\hline PP4 & My work is of high quality & 0.865 & \\
\hline PP5 & I always beat our team's target & 0.853 & \\
\hline \multirow[t]{2}{*}{ PP2 } & I get work done quickly and efficiently & 0.844 & \\
\hline & Employee Resilience & & $a=0.953$ \\
\hline RP3 & I can handle high workloads for long periods & 0.899 & \\
\hline RP1 & I effectively adapt to changes at work & 0.888 & \\
\hline RP5 & $\begin{array}{l}\text { I am constantly re-evaluating my performance and } \\
\text { working to improve the way I do my job }\end{array}$ & 0.887 & \\
\hline RP7 & $\begin{array}{l}\text { I know whom to contact at work when I need special skills } \\
\text { or support }\end{array}$ & 0.868 & \\
\hline RP4 & I try hard to solve problems at work & 0.857 & \\
\hline
\end{tabular}


THE ROLE OF E-TRAINING, CAREER DEVELOPMENT, AND EMPLOYEE RESILIENCE IN INCREASING EMPLOYEE PRODUCTIVITY IN INDONESIAN STATE-OWNED ENTERPRISES

\begin{tabular}{|c|c|c|c|}
\hline RP2 & $\begin{array}{l}\text { I collaborate effectively with others to handle unexpected } \\
\text { challenges }\end{array}$ & 0.853 & \\
\hline RP8 & I usually see change as an opportunity to grow & 0.844 & \\
\hline RP6 & I effectively respond to feedback, even criticism & 0.829 & \\
\hline \multirow[t]{2}{*}{ RP9 } & $\begin{array}{l}\text { I tend to find the positives in the most challenging } \\
\text { situations at work }\end{array}$ & 0.816 & \\
\hline & \multicolumn{2}{|l|}{ E-training } & $a=0.903$ \\
\hline PE4 & $\begin{array}{l}\text { The existing facilities and infrastructure in E-training of PT. } \\
\mathrm{SCl} \text { is very useful }\end{array}$ & 0.855 & \\
\hline PE6 & $\begin{array}{l}\text { E-training builds my confidence to solve problems on the } \\
\text { job }\end{array}$ & 0.855 & \\
\hline PE5 & $\begin{array}{l}\text { I will be able to use the new skills gained from the E- } \\
\text { training of PT. SCl for my professional career }\end{array}$ & 0.839 & \\
\hline PE3 & E-training provides curious material & 0.815 & \\
\hline PE7 & E-training creates a positive learning environment & 0.810 & \\
\hline \multirow[t]{2}{*}{ PE2 } & $\begin{array}{l}\text { The content of the training contained in E-training at PT. } \\
\mathrm{SCl} \text { can be applied to my work }\end{array}$ & 0.783 & \\
\hline & \multicolumn{2}{|l|}{ Career development } & $a=0.942$ \\
\hline PK1 & $\begin{array}{l}\text { I can give the impression that I am more competent than I } \\
\text { am }\end{array}$ & 0.910 & \\
\hline PK4 & $\begin{array}{l}\text { I am afraid my co-workers will reject me if I climb the } \\
\text { career ladder }\end{array}$ & 0.893 & \\
\hline PK7 & I feel confident taking on a leadership role & 0.880 & \\
\hline PK2 & $\begin{array}{l}\text { I was worried when I was proposed for promotion because } \\
\text { I did not know the requirements even though I wanted the } \\
\text { position }\end{array}$ & 0.867 & \\
\hline PK3 & I hope I do not fail to meet the requirements & 0.841 & \\
\hline PK6 & I have a strategy to achieve my career goals & 0.840 & \\
\hline PK5 & Overall, I am satisfied with myself & 0.806 & \\
\hline
\end{tabular}

Source: Data processed by author

Based on Table 3, it can be seen that the exploratory factor analysis resulted in four factors, employee productivity (0.910); employee resilience (0.953); e-training (0.903); and career development (0.942). According to this study, items with a low factor loading value, namely PE1 (online training provided by PT. SCl according to my work), are dropped during the analysis.

\subsection{Hypothesis testing}

This research uses structural model equations. Based on the measurement model testing carried out previously, it resulted in the feasibility of being a fit model because the model has met the reliability and 
Janna, N.N., Wolor, C.W., Suhud, U.

THE ROLE OF E-TRAINING, CAREER DEVELOPMENT, AND EMPLOYEE RESILIENCE IN INCREASING EMPLOYEE PRODUCTIVITY IN INDONESIAN STATE-OWNED ENTERPRISES

construct validity tests. The previous model has gone through confirmatory factor analysis, where several items need to be dropped to reach the fit model.

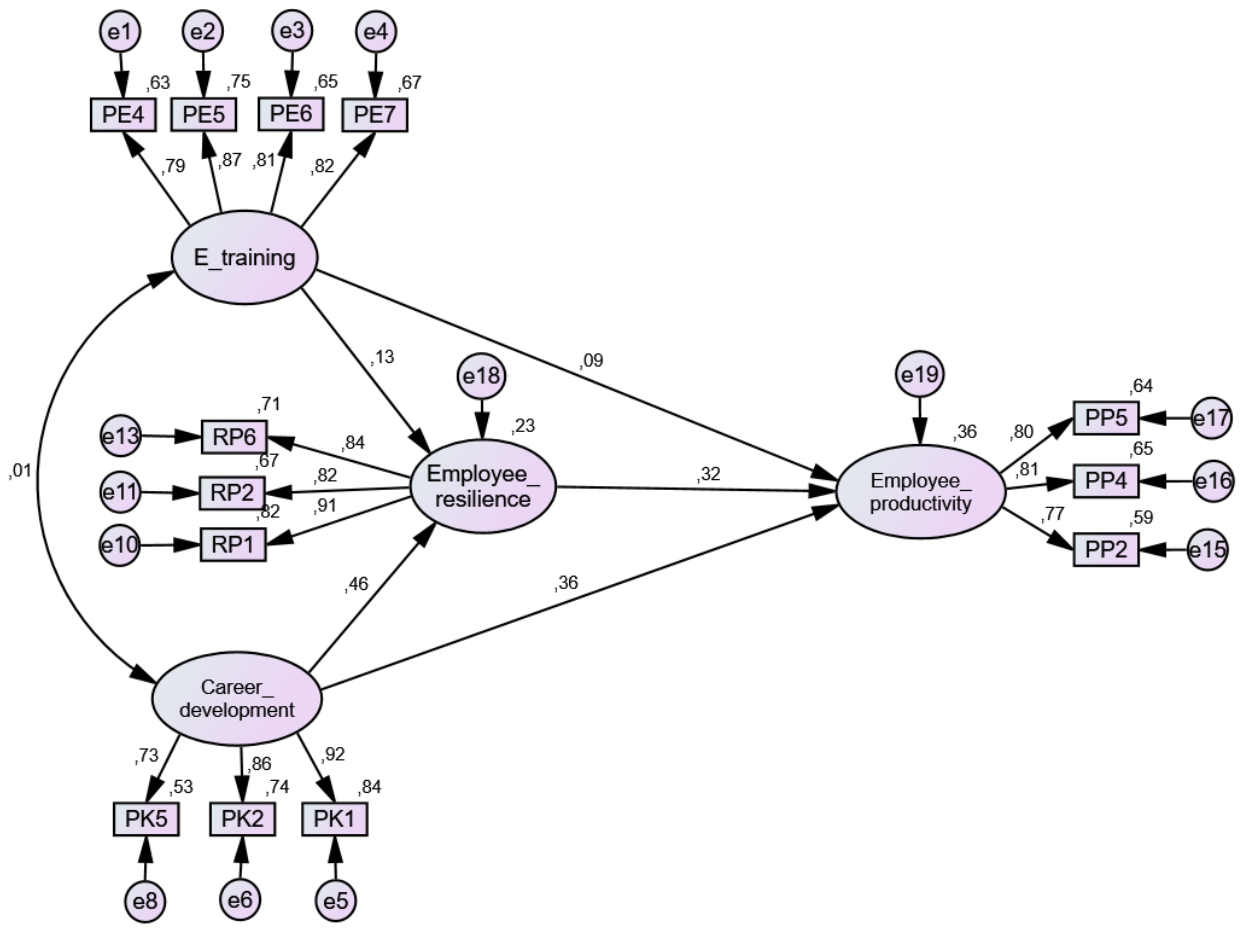

FIGURE 2. STRUCTURAL MODEL OF THE MODIFIED MODEL FIT

Source: AMOS output

Figure 2 shows the analysis of the modified structural model to produce a fit image according to the goodness of git parameter criteria suggested by Hair et al. (2014). The results of the goodness of fit output can be seen in Table 4.

TABLE 4. OUTPUT GOODNESS OF FIT MODIFIED STRUCTURAL MODEL ANALYSIS

\begin{tabular}{|l|c|c|c|}
\hline \multicolumn{1}{|c|}{ Criteria } & Cut-off Value & Results & Remarks \\
\hline Absolute Fit Indices & \multicolumn{3}{|c|}{} \\
\hline DF & $\geq 0$ & 59 & over Identified \\
\hline Chi-Square $\left(\mathrm{x}^{2}\right)$ & $\leq 77.930$ & 73.070 & \multirow{2}{*}{ good fit } \\
\hline Probability & $\geq 0,05$ & 0.103 & good fit \\
\hline CMIN/DF & $\leq 2$ (fit) & 1.238 & good fit \\
\hline GFI & $\geq 0,90$ & 0.959 & good fit \\
\hline RMSEA & $\leq 0,08$ & 0.030 & \\
\hline
\end{tabular}


THE ROLE OF E-TRAINING, CAREER DEVELOPMENT, AND EMPLOYEE RESILIENCE IN INCREASING EMPLOYEE PRODUCTIVITY IN INDONESIAN STATE-OWNED ENTERPRISES

\begin{tabular}{|l|c|c|c|}
\hline \multicolumn{1}{|c|}{ Criteria } & Cut-off Value & Results & Remarks \\
\hline RMR & $\leq 0.05$ & 0.019 & good fit \\
\hline Incremental Fit Indices & \multicolumn{3}{|c|}{} \\
\hline AGFI & $\geq 0,90$ & 0.937 & good fit \\
\hline NFI & $\geq 0,90$ & 0.964 & good fit \\
\hline TLI & $\geq 0,90$ & 0.991 & good fit \\
\hline CFI & $\geq 0,90$ & 0.993 & good fit \\
\hline IFI & $\geq 0,90$ & 0.993 & good fit \\
\hline RFI & $\geq 0,90$ & 0.953 & good fit \\
\hline Parsimonius Fit Indices & & & good fit \\
\hline PNFI & $\geq 0,50$ & 0.729 & good fit \\
\hline PCFI & $\geq 0,50$ & 0.751 & good fit \\
\hline PGFI & $\geq 0,50$ & 0.622 &
\end{tabular}

Source: Data processed by author

Based on Table 4, it can be concluded that the modified SEM model in this study is good because all criteria show a good fit value. The Chi-Square value shows a value of 73.070 with a P-value of 0.103 ( $\geq$ 0.05). A small chi-square value with a probability greater than the significance level indicates no significant difference between the predictive covariance matrix and the observed data. Furthermore, the value of CMIN/DF is $1,238(\leq 2)$, RMSEA is $0.030(\leq 0.08)$, RMR is $0.019(\leq 0.05)$. While GFI, AGFI, NFI, TLI, $\mathrm{CFI}, \mathrm{IFI}, \mathrm{RFI}$, the value of all criteria has exceeded the cut-off value of 0.90 . The value of the Parsimonious Fit Indices criteria, namely PNFI, PCFI, and PGFI, is already above the cut-off value of 0.50 . So it can be concluded that the structural model analysis can be said to be good and can be continued to test the hypothesis.

Hypothesis testing is done by using a t-value at a significance level of 0.05 . The test criteria are if the tvalue or critical ratio (C.R.) is 1.96, then the hypothesis is accepted. The C.R. and P-values in this study can be seen in table 5 .

TABLE 5. RESULT OF HYPOTHESIS TESTING

\begin{tabular}{|c|l|c|c|c|c|}
\hline Hypothesis & \multicolumn{1}{|c|}{ Path } & Estimate & C.R. & P & Results \\
\hline H1 & E-training $\rightarrow$ Employee Productivity & 0.217 & 1.491 & 0.136 & Rejected \\
\hline H2 & E-training $\rightarrow$ Employee Resilience & 0.279 & 2.159 & 0.031 & Accepted \\
\hline H3 & $\begin{array}{l}\text { Career Development } \rightarrow \text { Employee } \\
\text { Resilience }\end{array}$ & 0.611 & 7.273 & $* * *$ & Accepted \\
\hline
\end{tabular}


Janna, N.N., Wolor, C.W., Suhud, U.

THE ROLE OF E-TRAINING, CAREER DEVELOPMENT, AND EMPLOYEE RESILIENCE IN INCREASING EMPLOYEE PRODUCTIVITY IN INDONESIAN STATE-OWNED ENTERPRISES

\begin{tabular}{|c|l|c|c|c|c|}
\hline Hypothesis & \multicolumn{1}{|c|}{ Path } & Estimate & C.R. & P & Results \\
\hline H4 & $\begin{array}{l}\text { Career Development } \rightarrow \text { Employee } \\
\text { Productivity }\end{array}$ & 0.537 & 4.856 & $* * *$ & Accepted \\
\hline H5 & $\begin{array}{l}\text { Employee Resilience } \rightarrow \text { Employee } \\
\text { Productivity }\end{array}$ & 0.369 & 4.500 & $* * *$ & Accepted \\
\hline
\end{tabular}

Source: Research findings, processed by AMOS

Based on table 5, it can be seen that H1 has a C.R value. $1.491(\leq 1.96)$ with a probability level of 0.136 $(\geq 0.05)$, it can be concluded that $\mathrm{H} 1$ is rejected, meaning that e-training does not affect employee productivity. Then the C.R. at H2 of $2.159(\geq 1.96)$ with a P-value of $0.031(\leq 0.05)$, the research hypothesis is accepted. Then the C.R. on $\mathrm{H} 3, \mathrm{H} 4$, and $\mathrm{H} 5$ each have a value of 7,273, 4,856, 4,500 ( $\geq 1.96)$ with the resulting $\mathrm{P}$-value at $\mathrm{P} \leq 0.05$, where the ${ }^{* * *}$ sign is significant $\mathrm{P}<0.001$ then the research hypothesis is accepted.

\section{DISCUSSION}

The results of the study show that e-training has no significant effect on employee productivity. Therefore the e-training is less effective in increasing employee productivity. These results are in line with research conducted by Mwangi and Reuben (2019). Their research results state that $58 \%$ of employees in organizations do not agree with e-training because they have not fully met the skills and expertise needs of employees. The results of this study are supported by research conducted by Ramayah et al. (2012) that self-efficacy, ease of use, and training content are not significant. In addition, Dutton et al. (2002) research shows that users feel dissatisfied with e-learning systems and do not continue their training. When employees feel dissatisfied and do not continue their training, the training will not impact their productivity.

There is a significant effect of e-training on employee resilience, which means the implementation of etraining can increase employee resilience. According to Emmanuella (2020), being a resilient employee is a skill that can be learned, trained, and formed. Singh and Mohanty (2012) support that investing in training can improve employee skills in decision making, teamwork, problem-solving and interpersonal relationships. In addition, training can also affect employee behavior and work skills, which results in increased employee performance and constructive change (Satterfield \& Hughes, 2007).

Career development has a significant effect on employee resilience. The result is supported by Lyons et al. (2015), in their study that people who have their own career development goals are more resilient than those who do not have a thriving career, which means career development has a positive relationship 
with resilience. Career advancement opportunities can help employees deal with the stress they experience (Khan et al., 2019). In other words, career development can increase employee resilience. The results of this study are supported by research conducted by Lyons et al. (2015) and Srivastava and Madan (2020) which states that career development has a significant influence on employee resilience. The results of this study state that there is a significant influence between career development and employee productivity. This result follows the statement of Massie (2015) that career development and training can encourage the achievement of the best employee performance to provide increased productivity in the company. Another study that supports the results of this study is the research conducted by Kelana et al. (2016), Chen et al. (2004) stated that career development has a significant effect on employee productivity.

The results of the study state that employee resilience has a significant effect on employee productivity. Another study that states that employee resilience has a significant effect on employee productivity is research conducted by Zehir and Narcikara (2016) and Saifudin (2018). Stress felt by employees can reduce employee performance, productivity, morale, and stretch relationships at work (White, 2011) because employees who experience excessive stress have difficulty managing emotions, focusing attention, making decisions, and thinking clearly. According to Spangler et al. (2012), here are three main approaches that are effective in dealing with stress and resilience in the workplace, namely (a) preventing distress and building resilience; (b) provide information, resources, and benefits to employees; and (c) actively intervene with problematic employees.

\section{CONCLUSIONS AND RECOMMENDATION}

Based on the results, it can be concluded that one hypothesis is rejected, and four hypotheses are accepted. Career development is the main factor that can increase employee productivity and employee resilience. The results of this study have important implications for policymakers to determine company strategies related to e-training, career development, and employee resilience to increase employee productivity. The results of this study can also expand the literature related to increasing productivity in the Survey Service SOE environment. Therefore, it can provide opportunities for future research. It can be seen from the results of this study. It was found that the e-training variable had no impact on the results of the study. Further research can expand the research sample by including all survey service SOEs spread throughout Indonesia so that more optimal results can be found and can be generalized to areas wider.

This study proposes that companies must evaluate and improve the training system to make it more suitable for the needs of employees so that it can be applied to each employee's job or job desk but must 
keep up with the demands of the times so that the company can compete globally. Implementing online training programs and career development carried out in the company must be further improved so that management can filter out superior human resources to be prepared as the next generation of the company.

\section{REFERENCES}

Arifin, N. (2013). Manajemen sumber daya manusia: Teori dan kasus (Human resource management: Theories and cases). Jepara: UNISNU Press.

Batubara, H., H. (2018). Pelatihan e-learning berbasis moodle untuk dosen-dosen Universitas Islam Kalimantan MAB Banjarmasin (Moodle-based e-learning training for lecturers at the Islamic University of Kalimantan, MAB Banjarmasin). Journal of Character Education Society, 1(1), 57-66. https://doi.org/10.31764/jces.v1i1.115

Chen, T.-Y., Chang, P.-L., \& Yeh, C.-W. (2004). An investigation of career development programs, job satisfaction, professional development and productivity: The case of Taiwan. Human Resource Development International, 7(4), 441-463.

Cooper, R. D., \& Emory, C. W. (1996). Metode Penelitian Bisnis (Business Research Methods). Jakarta: Erlangga.

Dayona, G., \& Rinawati, N. (2016). Pengaruh pelatihan dan pengembangan karir terhadap employee engagement di PT Andalan Finance Indonesia (The effect of training and career development on employee engagement at PT Andalan Finance Indonesia). Jurnal Indonesia Membangun, 15(2), 39-61.

Din, R. (2010). Development and validation of an integrated meaningful hybrid e-training (i-met) for computer science theoretical-empirical based design and development approach. In Unpublished Dissertation, UKm, Malaysia.

Dutton, J., Dutton, M., \& Perry, J. (2002). How do online students differ from lecture students? Journal of Asynchronous Learning Network, 6(1), 1-20. https://doi.org/10.24059/olj.v6i1.1869

Emmanuella, R. (2020). Resiliensi karyawan dan produktivitas: sebesar ini kaitannya! (Employee resilience and productivity: this is how big the connection is!) Retrieved from Rilivstory website https://riliv.co/rilivstory/resiliensi-karyawan-dan-produktivitas/

Ginting, E. D. J. (2003). Hubungan persepsi terhadap progam pengembangan karir dengan kompentensi kerja (The relationship between perceptions of career development programs and work competence). Lecture's paper. Digitized by USU Digital Library.

Ghazali, I. (2017). Structural equation modeling konsep dan aplikasi dengan program amos 24 (Structural equation modeling concepts and applications with the amos 24 program). Semarang: Badan Penerbit Universitas Diponegoro.

Gyansah, S. T., \& Guantai, H. K. (2018). Career development in organizations: placing the organization and employee on the same pedestal to enhance maximum productivity. European Journal of Business and Management, 10(14), 40-45.

Hair, J. F., Black, W. C., Babin, B. J., \& Anderson, R. E. (2014). Multivariate Data Analysis. Essex: Pearson Education Limited. 
Hanaysha, J. (2016). Testing the effects of employee empowerment, teamwork, and employee training on employee productivity in higher education sector. International Journal of Learning and Development, 6(1), 164-178.

Heri, E. I. (2019). Tantangan pengembangan SDM Polri di era revolusi industri 4.0 (The challenges of developing Polri's human resources in the era of the industrial revolution 4.0). Jurnal IImu Kepolisian, 13.

Hodliffe, M. (2014). The development and validation of the employee resilience scale (EmpRes): The conceptualisation of a new model. Master's thesis, University of Canterbury, New Zealand.

Ilah, M. A., Indrawati, M., \& Prasetyo, I. (2020). Pengaruh pengembangan karir dan kompensasi terhadap kinerja melalui disiplin kerja karyawan di PT . Panasonic Gobel Eco Solutions Manufacturing Indonesia Pasuruan - Jawa Timur (The effect of career development and compensation on performance through work discipline of employees at PT. Panasonic Gobel Eco Solutions Manufacturing Indonesia Pasuruan - East Java). Jurnal Manajerial Bisnis, 3(3), 184-200.

llyas, M., Kadir, K. A., \& Adnan, Z. (2017). Relationship between training and employee productivity in organization: a partial least square (PLS-SEM) approach. Information and Knowledge Management, 7(3), 53-60.

Kelana, B. W. Y., Mansor, N. N. A., \& Sanny, L. (2016). The effect of HR sustainability practice to employee productivity in SMEs Malaysia. Information (Japan), 19(7B), 2815-2819.

Khan, Z., Rao-Nicholson, R., Akhtar, P., Tarba, S. Y., Ahammad, M. F., \& Vorley, T. (2019). The role of HR practices in developing employee resilience: a case study from the Pakistani telecommunications sector. International Journal of Human Resource Management, 30(8), 1342 1369. https://doi.org/10.1080/09585192.2017.1316759

Kuntz, J., Connell, P., \& Näswall, K. (2017). Workplace resources and employee resilience: The role of regulatory profiles. Career Development International, 22(4), 419-435.

Luthans, F., Norman, S. M., Avolio, B. J., \& Avey, J. B. (2008). The mediating role of psychological capital in the supportive organizational climate-employee performance relationship. Journal of Organizational Behavior, 29(2), 219-238. https://doi.org/10.1002/job.507

Luthans, F., Vogelgesang, G. R., \& Lester, P. B. (2006). Developing the psychological capital of resiliency. Human Resource Development Review, 5(1), 25-44.

Lyons, S. T., Schweitzer, L., \& Ng, E. S. W. (2015). Resilience in the modern career. Career Development International, 20(4), 363-383. https://doi.org/10.1108/CDI-02-2015-0024

Malaolu, V., \& Ogbuabor, J. E. (2013). Training and manpower development, employee productivity and organizational performance in Nigeria: an empirical investigation. International Journal of Advances in Management and Economics, 2(5), 163-177.

Massie, R., Tewal, B., \& Sendow, G. (2015). Pengaruh perencanaan karir, pelatihan dan pengembangan karir terhadap kinerja pegawai pada museum negeri Provinsi Sulawesi Utara (The influence of career planning, training and career development on employee performance at the state museum of North Sulawesi Province). Jurnal Bekala IImiah Efesiensi, 15(05), 635-645.

Mwangi, J., \& Reuben, J. M. (2019). Effects of e-recruitment and e-training on human resource performance: A case study of Telkom Kenya. International Journal of Research Publication, 43(1). https://doi.org/10035282019680

Nda, M. M., \& Fard, R. Y. (2013). The impact of employee training and development on employee productivity. Global Institute for Research \& Education, 2(6), 91-93. 
Neureiter, M., \& Traut-Mattausch, E. (2016). An inner barrier to career development: Preconditions of the impostor phenomenon and consequences for career development. Frontiers in Psychology, 7, 48, $1-15$.

Nguyen, Q., Kuntz, J. R. C., Näswall, K., \& Malinen, S. (2016). Employee resilience and leadership styles: The moderating role of proactive personality and optimism. New Zealand Journal of Psychology, 45(2), 13-21.

Nurshabrina, N., \& Adrianti, R. (2020). The Effect of E-Human Resource Management (E-HRM) on Cost Efficiency and Productivity of Employees in the Company. International Research Journal of Advanced Engineering and Science, 5(1), 212-215.

Permatasari, I. R. (2006). Pengaruh pengembangan karir terhadap kinerja karyawan: studi kasus di PT.Telkom Malang (The effect of career development on employee performance: a case study at PT. Telkom Malang). MODERNISASI, 2, 177-191.

Ramayah, T., Ahmad, N. H., \& Hong, T. S. (2012). An assessment of e-training effectiveness in multinational companies in Malaysia. Journal of Educational Technology \& Society, 15(2), 125-137.

Sabir, R. I., Akhtar, N., Ali, F., Bukhari, S., \& Nasir, J. (2014). Impact of training on productivity of employees: A case study of electricity supply company in Pakistan. International Review of Management and Business Research, 3(2), 595.

Saifudin. (2018). Hubungan antara resiliensi dengan produktivitas kerja pada karyawan perusahaan telekomunikasi PT. Cendana Teknika Utama (The relationship between resilience and work productivity on employees of the telecommunications company PT. Cendana Teknika Utama ). Undergraduate's thesis, UIN Maulana Malik Ibrahim, Malang

Satterfield, J. M., \& Hughes, E. (2007). Emotion skills training for medical students: A systematic review. Medical Education, 41(10), 935-941. https://doi.org/10.1111/j.1365-2923.2007.02835.x

Sihite, M. (2018). Peran kompetensi dalam mewujudkan sumber daya manusia yang berdaya saing tinggi di era revolusi industri 4.0: suatu tinjauan konseptual (The role of competence in realizing highly competitive human resources in the era of the industrial revolution 4.0: a conceptual review). Jurnal IImiah METHONOMI, 4(2), 145-159.

Singh, R., \& Mohanty, M. (2012). Impact of training practices on employee productivity: A comparative study. Interscience Management Review (IMR), 2(2), 74.

Smith, B., Shatté, A., Perlman, A., Siers, M., \& Lynch, W. D. (2018). Improvements in resilience, stress, and somatic symptoms following online resilience training: A dose-response effect. Journal of Occupational and Environmental Medicine, 60(1), 1.

Spangler, N. W., Koesten, J., Fox, M. H., \& Radel, J. (2012). Employer perceptions of stress and resilience intervention. Journal of Occupational and Environmental Medicine, 54(11), 1421-1429. https://doi.org/10.1097/JOM.0b013e3182619038

Srivastava, S., \& Madan, P. (2020). The relationship between resilience and career satisfaction: Trust, political skills and organizational identification as moderators. Australian Journal of Career Development, 29(1), 44-53. https://doi.org/10.1177/1038416219886317

Sultana, A., Irum, S., Ahmed, K., \& Mehmood, N. (2012). Impact of training on employee performance: A study of telecommunication sector in Pakistan. Interdisciplinary Journal of Contemporary Research in Business, 4(6), 646-661.

Vanhove, A. J., Herian, M. N., Perez, A. L. U., Harms, P. D., \& Lester, P. B. (2016). Can resilience be developed at work? A meta-analytic review of resilience-building programme effectiveness. Journal 
THE ROLE OF E-TRAINING, CAREER DEVELOPMENT, AND EMPLOYEE RESILIENCE IN INCREASING EMPLOYEE PRODUCTIVITY IN INDONESIAN STATE-OWNED ENTERPRISES

of Occupational and Organizational Psychology, 89(2), 278-307.

White, M. (2011). Building a Resilient organizational culture. Harvard Business Review, 1-13. https://hbr.org/2011/06/building-a-resilient-organizat

Yunita, N. W. (2018). Jurus Kemnaker ciptakan SDM di era teknologi digital. Retrieved from Detik Finance website https://finance.detik.com/berita-ekonomi-bisnis/d-3906226/jurus-kemnaker-ciptakan-sdmdi-era-teknologi-digital?_ga=2.91649244.753041431.1617536979-589614667.1617536979

Zehir, C., \& Narcıkara, E. (2016). Effects of resilience on productivity under authentic leadership. Procedia - Social and Behavioral Sciences, 235, 250-258. https://doi.org/10.1016/j.sbspro.2016.11.021 